\title{
Naturalism Presented in The Call of the Wild
}

\author{
Xiaofen Zhang \\ Dezhou University, Dezhou 253023, China \\ E-mail: dzzxf369@163.com
}

\begin{abstract}
Naturalism was first proposed and formulated by French novelist Emile Zola, and it was introduced to America by American novelist Frank Norris. It is a theory in literature emphasizing scientific observation of life without idealism or avoidance of the ugly. Naturalistic writers were influenced by the evolution theory of Charles Darwin. They believed that one's heredity and social environment determine one's character and influence the actions of its subjects. Jack London (1876-1916) was one of the most popular American writers of his time and regarded as one of the greatest naturalist novelists of America. He was deeply influenced by Darwin's ideas of constant struggle in nature and "the survival of the fittest. He showed his philosophy of naturalism completely in The Call of the Wild. The paper tries to explore the features of Naturalism in The Call of the Wild in an attempt to seek a deep understanding of naturalist literature.
\end{abstract}

Index Terms - naturalism, Jack London, The Call of the Wild

\section{INTRODUCTION}

\section{A. Jack London's Early Life}

Jack London (1876-1916) was born in San Francisco of an unmarried mother Flora Wellman. London grew up in extreme poverty: from earliest youth he supported himself with mental and dangerous jobs, experiencing profoundly the struggle for survival that most other writers and intellectuals knew only from observation or books. By the time he was eighteen he had worked in a cannery and as an oyster pirate, seaman, jute mill worker, and coal shoveler. Realizing that he could never become great by doing odd jobs, he determined to educate himself and prepare himself for better than grueling labor. He attended Oakland High School at age nineteen. A thirst for knowledge snatched young London and he read every book he could get. London consciously chose to become a writer to escape from the horrific prospects of life as a factory worker.

\section{B. His Works}

He read many philosophical books and his philosophical thoughts were greatly influenced by the four great teachers of him: Darwin, Spencer, Marx and Nietzsche. London believed in Darwin's evolutionary theory of "survival of the fittest." He studied other writers and began to submit stories, jokes, and poems to various publications, mostly without success. "Fate brought him the answer and gold was found in Klondike" (Pizer, 1984). On July 12, 1897, London and his brother-in-law, James Shepard, sailed to join the Klondike Gold Rush where he would later set his first successful stories. London's time in the Klondike, however, was quite detrimental to his health. Fortunately London survived the hardships of the Klondike. Spending the winter of 1897 in the Yukon provided the metaphorical gold for his first stories. There he got familiar with the northern life and especially with kinds of dogs. The materials he collected there prepared him for the writing of his two famous novels The Call of the Wild (1903) and White Fang (1906) and his other early works that are a series of short stories called "northern stories". Most of them are adventurous stories set in a primitive environment and they relive the scene of Klondike gold rush and describe the hard and mysterious life of the god-seekers, their strong will and persistence in fighting with nature, and also a series of conflicts among the fellow men in the wilderness, in the valley and in the huts. London read many books and believed in Darwin's evolutionary theory of "survival of the fittest" and also Nietzsche's superman. Both his experience and the philosophical thoughts affected his character, his mind and hence his works. He became one of the most popular American writers of his time and regarded as one of the greatest naturalist novelists of America. He had been in the forefront of the move toward naturalistic fiction and realism in America. He showed his philosophy of naturalism completely in The Sea-Wolf, White Fang and The Call of the Wild.

\section{SUMMARY OF THE CALL OF THE WILD}

The Call of the Wild is a novel by Jack London. The plot concerns a previously domesticated and somewhat pampered dog named Buck, whose primordial instincts return after a series of events.

Buck lived at a big house in the sun-kissed Santa Clara Valley. During the four years since his puppy hood he had lived the life of a sated aristocrat. Buck's first owner was Judge Miller, who took good cares of him. But one day, his life changed. Manuel, who was one of the Judge's employees - a gardener's helper cheated him and sold him to a strange man. From then on, his frustrated life began. He hated the new master, a man in a red sweater, he jumped at the man, and barking. But the man beat him down to the ground. Finally he submitted to the man. In the treacherous, frigid Yukon, he served as a sled dog. The bad weather, the terrible Husky dogs, his dead friend, the fights, especially with Spitz, a Cunning 
lead dog in Perrault's team and rival of Buck, and many things made Buck knew he was surrounded by savages... Buck realized there was no goodness and kindness in this world. There was only one rule: dead or kill; eat or be eaten off. There was no fair play. Only fight and war could help him. Finally, he began to master his new surroundings. His ability to rule and his great intelligence and good judgment were wonders to everyone. Then, Buck was sold once more. He had two stupid owners. And then John Thornton rescued Buck. Buck loved Thornton as he had loved no other man, for Thornton treated him as if he were his own child. Yet Buck also had a deep yearning for the wilds, which the rough northern climes awakened in him. One day, on his way back to Thornton's camp, he smelled strangers and senses something is wrong. The Yeehats, an Indian tribe killed all the people, include John. Buck was very angry, and he killed most of the Yeehats. He was very proud of himself, because he killed people. John was dead. Buck's last tie with people was broken. Finally, he was ready to answer the call of the wild. He often listened to some special voice of the wild. He ran with wolves, side by side with his wild brothers, shouted as he ran. Sometimes, he raised his great head, and with the wolves, he sounded the call of the wild. That's the most wonderful voice and future for Buck.

\section{NATURALISM}

Webster's Dictionary gives naturalism a concise definition: A made of thought (religious, moral or philosophical) glorifying nature and excluding supernatural and spiritual elements close adherence to nature in art or literature, esp. (in literature) the technique, chiefly associated with Zola, used to present a naturalistic philosophy, esp. by emphasizing the effect of heredity and environment on human nature and action (The Webster's Dictionary of the English Language, 1989, p. 667). Naturalism was first proposed and formulated by Emile Zola, the French writer and theorist, who is universally labeled as the founder of literary naturalism. Naturalism was a literary movement taking place from 1865 to 1900. A literary work should present life exactly as it is. The naturalist writer also attempted to be painstakingly scientific, objective and detached observation of life without idealism or avoidance of the ugly. It emphasizes that social conditions, heredity, and environment have inescapable force in shaping human character. Naturalistic writers were influenced by the evolution theory of Charles Darwin. They believed that one's heredity and social environment determined one's character and influenced the actions of its subjects.

\section{NATURALism PRESENTED IN THE CALl OF THE WILD}

\section{A. Determinism Theory of Heredity-Atavism: Hearing and Responding to the Call of the Wild}

At the beginning of The Call of the Wild, Jack London presents a quotation from "Atavism," a 1902 poem by John Myers O'Hara that encapsulates one of the main motifs of the novel:

"Old longings nomadic leap,

Chafing at custom's chain;

Again from its brumal sleep [brumal: winter]

Wakens the ferine strain." [ferine: savage, fierce, wild]

One characteristics of naturalism is Determinism theory of Heredity. In the novel heredity is mainly represented in "atavism". "Atavism" is one of the themes of the call of the wild. It is an animal's recovery of the instincts of his wild ancestors.

For Buck, this recovery involved repeated visions of his primitive past, which usually occurred late at night when he was lying alongside a campfire. Buck had visions in which he and a hairy man traipsed through the wilds long ago, in some primordial age. The man could leap high and swing in trees. "And closely akin to the visions of the hairy man was the call still sounding in the depths of the forest. It filled him with a great unrest and strange desires. It caused him to feel a vague, sweet gladness, and he was aware of wild yearnings and stirrings for he knew not what. Sometimes he pursued the call into the forest, looking for it as though it were a tangible thing, barking softly or defiantly, as the mood might dictate." (Chapter VII, "The Sounding of the Call"). Buck's experiences in the northland wilderness awakened in him the long-dormant instincts of a wild carnivore. When he acted on these instincts-by killing the moose, for example, or befriending the "wolf brother"-he was responding to the call of the wild. His atavism-that was, his reversion to the behavior of his canine ancestors-gradually transformed him into a wolf like creature that prefers to live in a savage environment in which he must fight and kill to live.

In the last chapter of The Call of the Wild, there was always a scene that Buck felt the call of the life in the wild drawing him away from mankind, away from campfire and towns, and into the forest. The only thing that prevented him from going and kept him tied to the world was his master, his love for John Thornton. Buck loved Thornton as he had loved no other man, for Thornton treated him as if he were his own child. If he had been the charge of a less worthy man, he would have run off and become part of the wilds. Yes, Buck acted at times like a house dog as he sat next to Thornton's fire. "But behind him were the shades of all manner of dogs, half-wolves and wild wolves, urgent and prompting, tasting the savor of the meat he ate, thirsting for the water he drank, scenting the wind with him, listening with him and telling him the sounds made by the wild life in the forest, dictating his moods, directing his actions, lying down to sleep with him when he lay down, and dreaming with him and beyond him and becoming themselves the stuff of his dreams. " (Chapter VI, "For the Love of a Man"). 
When Buck found the dead body of John Thornton killed by Yeehats in a pool of water, it was at this moment that Buck completed his transition from servant of man (or, in the case of Thornton, friend of man) to wild animal free and unattached. While brooding over Thornton's body, he heard and answered the call of the wild:

"From far away drifted a faint, sharp yelp, followed by a chorus of similar sharp yelps. As the moments passed the yelps grew closer and louder. . . It was the call, the many-noted call, sounding more luringly and compellingly than ever before. And as never before, he was ready to obey. John Thornton was dead. The last tie was broken. Man and the claims of man no longer bound him." (Chapter VII, "The Sounding of the Call"). Buck killed a number of Yeehats, "stealing from their camps in fierce winters, robbing their traps, slaying their dogs, and defying their bravest hunters" (Chapter VII, "The Sounding of the Call"). Some of their hunters want into the forest but never returned, for the Ghost Dog had come upon them and slashed their throats. To attack or kill a human being would once been unthinkable for Buck, and his willingness to do so now symbolized the fact that the docile, pet dog, had been transformed into a beast that killed with impunity and without any kind of remorse.

\section{B. Determinism Theory of Environment - "Survival of the Fittest"}

Naturalism also emphasizes that environment has inescapable force in shaping human character and influencing the actions of its subjects. In Naturalism, characters have no free will, extended and internal forces, while environment or heredity controls their behavior. This is just determinism. All determinists believe in the existence of the will, but the will is often enslaved on account of different reasons. Jack London's naturalism could primarily be attributed to the fact that he was an ardent exponent of and a firm believer in the "survival of the fittest" theory. This concept, according to him, is a matter of the violence of force against force - the weak dwindle into insignificance and perish. There was no room for the weak in London's world. Only the strong prevailed and inhabited the hard world. For the main character Buck, from a civilized, gentle, moral, tame, and happy-go-lucky domestic pet dog to a wild, cruel, leader of the wolves, besides heredity, it was the environment that transformed Buck and his adaptation made him survive in the cruel world.

On Judge Miller's vast estate in sunny Santa Clara Valley, California, four-year-old Buck was the top dog. He lived comfortable life. "The whole realm was his," "He plunged into the swimming tank or went hunting with the Judge's sons; he escorted Mollie and Alice, the Judge's daughters, on long twilight or early morning rambles; on wintry nights he lay at the Judge's feet before the roaring library fire; he carried the Judge's grandsons on his back, or rolled them in the grass, and guarded their footsteps through wild adventures down to the fountain in the stable yard, and even beyond, where the paddocks were, and the berry patches" (Chapter I, "Into the Primitive"). But In the hostile living environment in the North land, Buck not only adapted him self to the new circumstances, he had learned well the law of club and fang. While a man in a red sweater opened the crate and releases Buck, immediately Buck sprang at him, but the man dealt him a brutal blow with a club. A dozen times he charged, and as often the club broke the charge and smashed him down. Dazed and drained of energy, Buck now realizes that he could not compete with the club. He learned to subdue his rage and remained where he has fallen. "You've learned your place, and I know mine," the man says (Chapter I, "Into the Primitive"). Over the next few days, the man similarly greeted other dogs-some docile and some defiant like Buck. One dog that continued to resist died under the club.

On the trail, he was a fast learner. He learned how to dig a snow shelter for cold nights and how to answer the stop and go commands, ho and mush. He quickly mastered the ways of the sled dog. In the north, Buck knew the furious fights between the dogs, and the death. Buck first realized the importance of the sharp teeth in the competition. There was a strong dog, Spitz. He often bullied the weaker, even Buck. He often ate the other's food; let them hunger. He often slept the other's comfortable hole, made the other sleep in the wind yard in snowy winter night. So Buck decided to have a fight with the Spitz, live or death, happy or suffering. In fighting with Spitz, although he was strong, he was serious damaged. But he did not give up. He knew that once a dog was down on the ground, he was dead, a loser. The laughing of the Spitz enraged him. Finally, he alters his tactics after first failing to penetrate his foe's defenses and kills Spitz. Buck took up the duties of leadership. "Buck was merciless. He had learned well the law of club and fang, and he never forewent an advantage or drew back from a foe he had started on the way to Death. He had lessoned from Spitz, and from the chief fighting dogs of the police and mail, and knew there was no middle course. He must master or be mastered; while to show mercy was a weakness. Mercy did not exist in the primordial life. It was misunderstood for fear, and such misunderstandings made for death. Kill or be killed, eat or be eaten, was the law; and this mandate, down out of the depths of Time, he obeyed."(Chapter VI. For the Love of a Man. London, 1994: 63)

In the wilds, he himself became wild, stalking and killing prey, including a moose. One day, Buck encountered a wolf pack. One attacked him, but Buck broke his neck. Three others then set upon him, but they retreat after Buck rips them open. When the other wolves close in, Buck holds them off, whirling left and right with snapping jaws. Finally, a wolf approaches him docilely and rubs noses with him. It is the wolf Buck romped with earlier in the forest. Then an old wolf came forward and, with a howl, welcomed Buck into the pack. Eventually he became the leader of a wolf pack. Buck's strength and courage supported him through his ordeals. However, more than anything else, it was his ability to adapt to his environment that ensures his survival.

In contrast to Buck, the good-natured Newfoundland, Curly, failed to survive because she acted civilly in a savage environment. She did not adapt. As an animal, Buck's behaviors represented "the survival of the fittest." He was struggling for his life. Facing trouble, to survive was the most important thing. He must adapt to the new environment and defeat the other animals so that he can survive. From portraying the dog's images to revealing the formation and 
development of the dog's character, the novel embodies obviously genetic determinism and environmental determinism advocated by Zola. Darwin's theory of "the big fish eat up the small, the fittest survive" is fully expressed through Buck's image.

\section{Objective}

The naturalist strives to be objective and detached, even documentary in his presentation of material; the naturalist writer prefers to observe the characters as if they were animals in the wild and then report on their activity. In the world of jungle, to exist is the most important. So the naturalists adopt an immoral attitude toward human life, and they neither criticize nor praise human beings' actions. The naturalists don't hide or avoid the existence of the dark side of society, and they describe the dark side honestly. The characters in the works of naturalism are unsavory. They pay no attention to morals and they offend public decency, they often act against the social norms or against their will under the pressure of circumstances. Buck's image reflects the character of naturalism in literature: there is only the cruel fight to survive and no human sympathy there. Buck must defeat the other animals so that he can survive. It is the same with human beings who must invade and defeat other people so that they can gain their place in the society.

Nietzsche (1844-1900) developed the concept of the Übermensch, or superman, a person who attains superior status in society after mastering himself and exhibiting a "will to power" and creative use of his energies. In Also Sprach Zarathustra (Thus Spake Zarathustra), Nietzsche enunciated his Übermensch theory, saying the achievement of superman status requires the individual to reject democracy, modern civilization, religion, and western morality because they inhibit him from realizing his full potential. London loosely applied some principles of Nietzsche's complex philosophy to Buck, as demonstrated when Buck mastered his passions and achieves dominance through creative use of his powers. In the end, Buck choose to forsake civilization and lived in the wilds as an "über" wolf-that was, the leader of the pack.

The characters in the works of naturalism are usually dominated by the fundamental desires to live such as fear, hunger, and sexual desire etc. In the world of jungle, to exist is the most important. So the naturalists adopt an immoral attitude toward human life, and they neither criticize nor praise human beings' actions. The naturalists don't hide or avoid the existence of the dark side of society, and they describe the dark side honestly. The characters in the works of naturalism are unsavory. They pay no attention to morals and they offend public decency, they often act against the social norms or against their will under the pressure of circumstances. Buck's image reflects the character of naturalism in literature: there is only the cruel fight to survive and no human sympathy there. There are no rules there, the only rule is massacring and reeking of blood. This is against traditional moral doctrines. But it is just one feature of literary naturalism.

\section{CONCLUSION}

In conclusion, American naturalism is an important literary trend and it is influential to realism and also modernism. As a famous writer, London played an important part in the naturalistic trend, and he made great contribution to the world's literary history. He was strongly influenced by Darwin's theory of evolution. The determinism and "the big fish eat up the small, the fittest survive" theory of naturalism are clearly shown in the novel. The Call of the Wild exposes the essence of human's life: from the society perspective, there seems to be only one law in this world, which both men and beasts obey - only the fittest can survive in the strongly competitive world. Buck's struggles toward independence can symbolize the struggles every human faces in life. We should learn something from Buck, who progresses toward independence after learning to cope in a hard world.

\section{REFERENCES}

[1] London, Jack. (1994). The Call of the Wild. Beijing: Foreign Language Teaching and Research Press.

[2] The Webster's Dictionary of the English Language.(1989). Lexicon Publications.

[3] Zola, (1988). Naturalism . Beijing: China Social Sciences Press.

[4] Donald, Pizer. (1984). Realism and Naturalism in Nineteenth-Century American Literature. Southern Illinois University Press.

[5] Weiren, Wu. (1990). History and Anthology of American Literature Volume 2. Foreign Language Teaching and Research Press.

[6] Xinguo, Ma. (1994). History of Western Literary Theory. Beijing: Higher Education Press.

[7] Wen, Zhu.(1992). Naturalism in Literature. Shanghai: Shanghai Art and Literature Publishing House.

[8] The Project Gutenberg EBook of The Call of the Wild. http://www.gutenberg.org/files/215/215-h/215-h.htm.

[9] Michael J. Cummings. (2008). The Call of the Wild (A Study Guide). http://www.cummingsstudyguides.net.

[10] Wikipedia, the free encyclopedia. Web Transcription Tool. http://en.wikipedia.org/wiki/Jack London

[11] Wikipedia, the free encyclopedia. Web Transcription Tool. http://en.wikipedia.org/wiki/Naturalism (literature).

Xiaofen Zhang was born in Dezhou, China in 1963. She graduated from the English Department of Dezhou University, Shandong Province, China in 1986. She received her B.A. degree in ELT (English language teaching) from Liaocheng University, Shandong Province, China in 1996.

She is currently an associate professor in Dezhou University, China. Her research interests include English language and American literature. 